Влијанието на локалните власти врз намалувањето на невработеноста кај младите и нивната перцепција за работата на локалните власти во областа на вработувањето во Општина Јегуновце и Општина Чаир

Др. Агрон Рустеми

Др. Мемет Мемети Факултетот за Јавна Администрација и Политички науки при JИЕУ

- Тетово

a.rustemi@seeu.edu.mk, m.memeti@seeu.edu.mk

Невработеноста е френомен кој што во Република Македонија е присутен речиси од независноста па до ден денес. Освен централната власт која според легислатива во Република Македонија има поголеми ингеренции во врска со политиките на вработување и локалната власт може да придонесе врз намалување на невработеноста преку политиките на локалниот економски развој. Во овој труд се анализирани различните теоретски пристапи за поимот на невработеноста, факторите кои се поврзани со невработеноста и импактот на невработеноста

\section{The influence of the local government on reducing youth unemployment and youth perception on the work of local authorities in the area of employment in the Jegunovce and Cair Municipality}

PhD Agron Rustemi PhD Memet Memeti Faculty of Public Administration and Political Science at South East European University - Tetovo

a.rustemi@seeu.edu.mk, m.memeti@seeu.edu.mk

Unemployment is one of the most prevalent issues that the Republic of Macedonia has faced since its independence. In addition to the central government which is responsibility for the design and implementation of policies in the area of employment, the local government another important actor, who can contribute in this area, through the local economic development policies. This article will analyze various theoretical approaches of the concept of unemployment, factors that are associated with unemployment and the impact of unemployment on the 
врз целокупната благосостојба на граѓаните како и перцепцијата на граѓаните за невработеноста во општините Јегуновце и Чаир.

Во текстот освен теоретскиот ќе се анализира и влијанието на локалните власти на две општини, една рурална (Општина Јегуновце) и една урбана (Општина Чаир). Податоците се добиени со помош на емпириско истражување (анкета и интервју) преку која се анализира мислењето на граѓаните а особено на младите за тоа колку добро нивната општина се справува со ова проблематика и дали младите имаат доверба и гледаат перспектива во нивната општина како место за вработување и просперитет. Ќе се анализираат две општини и тоа една урбана општина која што е дел од главниот град и една рурална општина за да се направи и компаративна анализа со цел да се дознае дали младите во една рурална општина мислат дека имаат помалку перспектива за вработување отколку младите во една урбана средина.

Темата сигурно ќе привлече интерес како од научните кругови така и пошироката јавност затоа што несомнено едно од клучните прашања во Македонија е невработеноста на младата популација која е основен двигател на миграционите процеси во нашата држава.

Клучни зборови: Вработување, Општина Јегуновце, Општина Чаир, локална власт, мерки, политики за вработување. overall well-being of citizens as well as the perception of citizens on unemployment in the municipalities of Jegunovce and Cair.

In addition to the above theoretical part, this article will also study the influence of local government including two Municipalities, one rural (Jegunovce Municipality) and one urban (Cair Municipality). The data will be obtained through an empirical research (survey and interview) surveying the citizens' opinion, especially of young people, about the way their municipality handles this issue and whether young people have confidence and see in their municipality a perspective of employment and prosperity. This approach will enable a comparative analysis of these two municipalities about the perception of youth in regard to employment in both rural and urban area.

The article will certainly attract attention of both the scientific milieus and the general public in the country, as it is evident that unemployment is the main catalyst of migration processes within and out of Macedonia.

Keywords: Employment, Jegunovce Municipality, Cair Municipality, local government employment policy, measures. 


\section{Осврт на поимот} на невработеноста

Постојат многу дефриниции кои го опишуваат поимот невработеност, тие се слични и се надополнуваат едни на други. Пример за стандардната дефиниција на невработеност е Лица кои се времено невработени, без формален работен договор, кои во моментов се на располагање за работа и бараат работа. Друга слична дефиниција е дадена од страна на Меѓународната организација на трудот, според која: лица без работа и моментно расположливи за работа кои сакат да се вработат преку вработување или само вработување активност на датум по поднесувањето на рефрерентниот период се сметаат за невработени.

Според друга дефиниција, поединецот кој има 16 години или е постар, не е институционализиран (на училиште, во воена служба, пензионери), не работи за одреден временски период наведен во националното законодавство (на пример, една недела), и бара нова работа како невработен.

Бидејќи долгорочната масовна невработеност не постоеше пред големата депресија, економистите го третираат вишокот на пазарот на трудот, како специфичен економски

\section{Definition of Unemployment}

Unemployment is a situation in which the number of people willing to work for a prevailing wage is higher than the available jobs. As such, unemployment can be economically described as a surplus in the labor market. The size of unemployment is measured by unemployment rate, which is a ratio of total unemployment to the total labour force, where the latter is the sum of employed and unemployed people.

There are many definitions describing unemployment, often similar and complementary. In order to understand better the issue of unemployment we have the standard definition of persons temporarily absent from their jobs with no formal job attachment who are currently available for work and seeking work. Another similar definition is given by The International Labor Organization, according to which: persons without work and currently available for work who had made arrangements to take up paid employment or undertake self-employment activity at a date subsequent to the reference period should be considered as unemployed. Or another definition points out at an individual who is 16 years of age or older, is not institutionalized (at school, in military service, retired), did not work for a particular period specified in the national legislation (for ex- 
феномен кој го анализира сурплусот на понудата виза ви побарувачката. Од втората половина на 20 век на површина излегуваат специфични политики за борба против невработеноста, бидејќи неможноста да се најде работа доведе до влошување на економската ситуација на луѓето (Encyclopedia of World Poverty 2006).

\section{Општи показатели \\ за невработеноста во Македонија}

Според податоците на Државниот завод за статистика, во І-то тримесечје од 2013 година активното население во Република Македонија брои 953.780 лица од кои вработени се 668.957, 284.823 лица се невработени.

Стапката на активност во овој период е 57.0, стапката на вработеност е 40.0, додека стапката на невработеност е 29.9. ${ }^{1}$

Од кои населението на возраст од 15 години и повеќе, според полот изнесува: Вкупно невработени мажи 174999. Или $61,4 \%$, и вкупно невработени жени 109824 или 38,6 \%, од вкупниот број на невработени лица.

http://www.stat.gov.mk/pdf/2013/2.1.13.18.pdf ample, one week), and seeks a new job as unemployed.

Since long-term mass unemployment had not existed prior to the Great Depression, economists treated the surplus in the labour market as one particular application of the general economic phenomenon surplus of quantity supplied over quantity demanded. Only in the second half of the 20th century did unemployment policies, specifically designed to fight unemployment, reach the status of a major political and public concern, as the impossibility to find a job is indeed a reason for economic hardship among the masses of people (Encyclopedia of World Poverty 2006).

\section{General indicators of unemployment in Macedonia}

According to the State Statistical Office, in the first quarter of 2013, the labour force in the Republic of Macedonia numbered 953,780 persons, of which 668,957 were employed and 284,823 were unemployed.

The activity rate in this period was 57.0 and the employment rate was 40.0 , while the unemployment rate was 29.9. ${ }^{1}$

The unemployment rate in the population aged 15 years and more, distributed by gender was: 174,999 or $61.4 \%$ men, and 109,824 or $38.6 \%$ women of the total number of unemployed.

\footnotetext{
http://www.stat.gov.mk/pdf/2013/2.1.13.18.pdf
} 
Табела 1. Население на возраст од 15 години и повеќе, според економската активност и полот

Table 1. Population aged 15 years and more, by economic activity and gender

\begin{tabular}{|c|c|c|c|c|}
\hline & \multicolumn{2}{|c|}{$\begin{array}{l}\text { I тримесечје, } 2013 \\
\text { I quarter, } 2013\end{array}$} & \multirow[t]{2}{*}{$\begin{array}{l}\text { I } 2013 \\
\text { I } 2012\end{array}$} & \\
\hline & лица & $\begin{array}{l}\text { структура по пол } \\
\text { structure by gender }\end{array}$ & & \\
\hline $\begin{array}{l}\text { Активно } \\
\text { население } \\
\text { Labour Force }\end{array}$ & & & & $\begin{array}{l}\text { Активно } \\
\text { население } \\
\text { Labour Force }\end{array}$ \\
\hline $\begin{array}{l}\text { Bкупно } \\
\text { Total }\end{array}$ & 953780 & 100.0 & 101.4 & $\begin{array}{c}\text { Вкупно } \\
\text { Total }\end{array}$ \\
\hline $\begin{array}{c}\text { Мажи } \\
\text { Men }\end{array}$ & 569967 & 59.8 & 100.0 & $\begin{array}{c}\text { Мажи } \\
\text { Men }\end{array}$ \\
\hline $\begin{array}{l}\text { Жени } \\
\text { Women }\end{array}$ & 383813 & 40.2 & 103.5 & $\begin{array}{l}\text { Жени } \\
\text { Women }\end{array}$ \\
\hline $\begin{array}{r}\text { Вработени } \\
\text { Employed }\end{array}$ & & & & $\begin{array}{r}\text { Вработени } \\
\text { Employed }\end{array}$ \\
\hline $\begin{array}{l}\text { Вкупно } \\
\text { Total }\end{array}$ & 668957 & 100.0 & 103.9 & $\begin{array}{c}\text { Вкупно } \\
\text { Total }\end{array}$ \\
\hline $\begin{array}{c}\text { Мажи } \\
\text { Men }\end{array}$ & 394968 & 59.0 & 103.0 & $\begin{array}{c}\text { Мажи } \\
\text { Men }\end{array}$ \\
\hline $\begin{array}{l}\text { Жени } \\
\text { Women }\end{array}$ & 273989 & 41.0 & 105.3 & $\begin{array}{l}\text { Жени } \\
\text { Women }\end{array}$ \\
\hline $\begin{array}{l}\text { Невработени } \\
\text { Unemployed }\end{array}$ & & & & $\begin{array}{r}\text { Невработени } \\
\text { Unemployed }\end{array}$ \\
\hline $\begin{array}{l}\text { Bкупно } \\
\text { Total }\end{array}$ & 284823 & 100.0 & 95.8 & $\begin{array}{c}\text { Вкупно } \\
\text { Total }\end{array}$ \\
\hline $\begin{array}{c}\text { Мажи } \\
\text { Men }\end{array}$ & 174999 & 61.4 & 93.7 & $\begin{array}{c}\text { Мажи } \\
\text { Men }\end{array}$ \\
\hline $\begin{array}{l}\text { Жени } \\
\text { Women }\end{array}$ & 109824 & 38.6 & 99.3 & $\begin{array}{l}\text { Жени } \\
\text { Women }\end{array}$ \\
\hline $\begin{array}{l}\text { Неактивно } \\
\text { население } \\
\text { Inactive } \\
\text { population }\end{array}$ & & & & $\begin{array}{l}\text { Неактивно } \\
\text { население } \\
\text { Inactive } \\
\text { population }\end{array}$ \\
\hline $\begin{array}{l}\text { Вкупно } \\
\text { Total }\end{array}$ & 719181 & 100.0 & 98.9 & $\begin{array}{c}\text { Вкупно } \\
\text { Total }\end{array}$ \\
\hline $\begin{array}{c}\text { Мажи } \\
\text { Men }\end{array}$ & 266667 & 37.1 & 101.0 & $\begin{array}{c}\text { Мажи } \\
\text { Men }\end{array}$ \\
\hline $\begin{array}{l}\text { Жени } \\
\text { Women }\end{array}$ & 452514 & 62.9 & 97.8 & $\begin{array}{l}\text { Жени } \\
\text { Women }\end{array}$ \\
\hline
\end{tabular}

Извор: Државен завод за статистика (2013) Македонија во бројки.

Source: State Statistical Office (2013) Macedonia in numbers. 
Графикон 1. Невработеноста според должината на невработеност

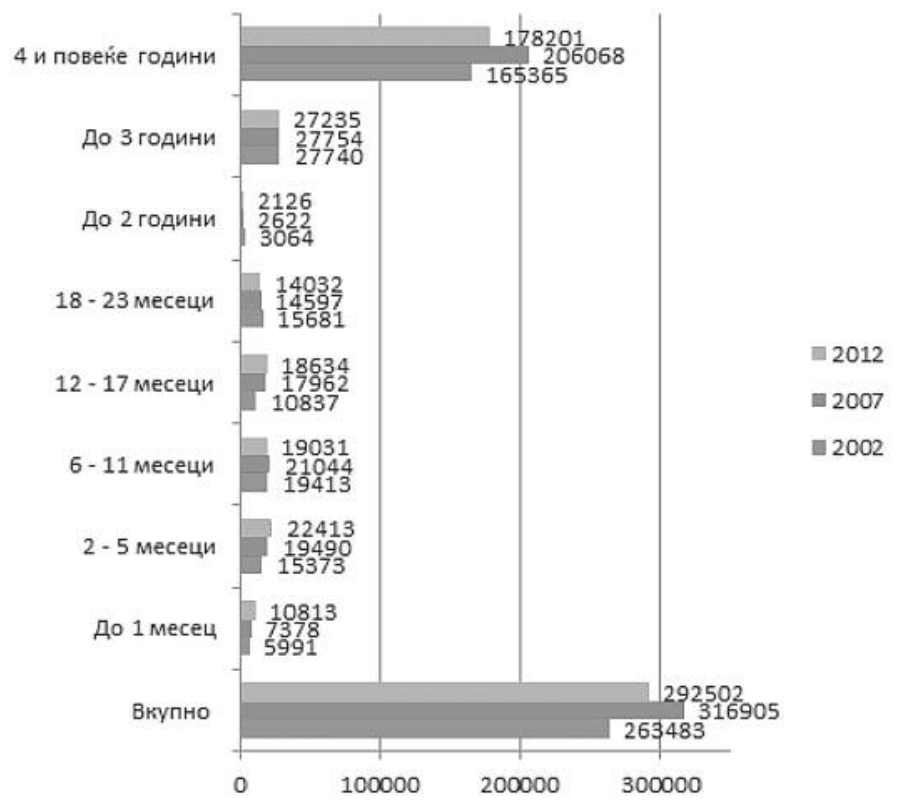

Извор: Државен завод за статистика (2013) Македонија во бројки.

Chart 1. Unemployment by duration of unemployment

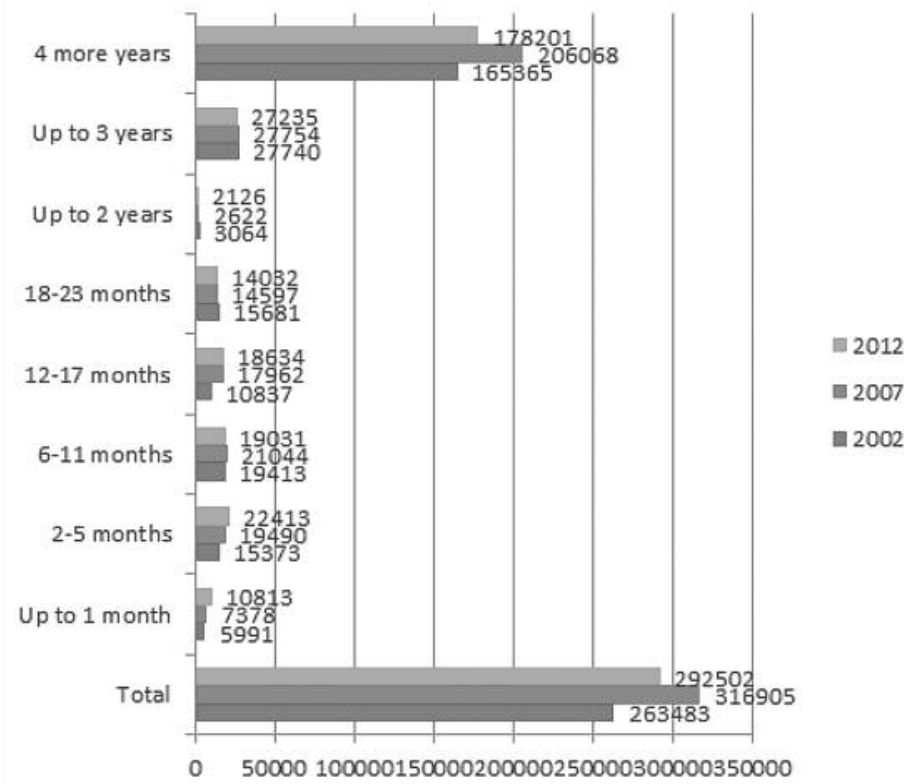

Source: State Statistical Office (2013) Macedonia in numbers. 
Грасрикон 2. Невработени по возрасни групи, 2012

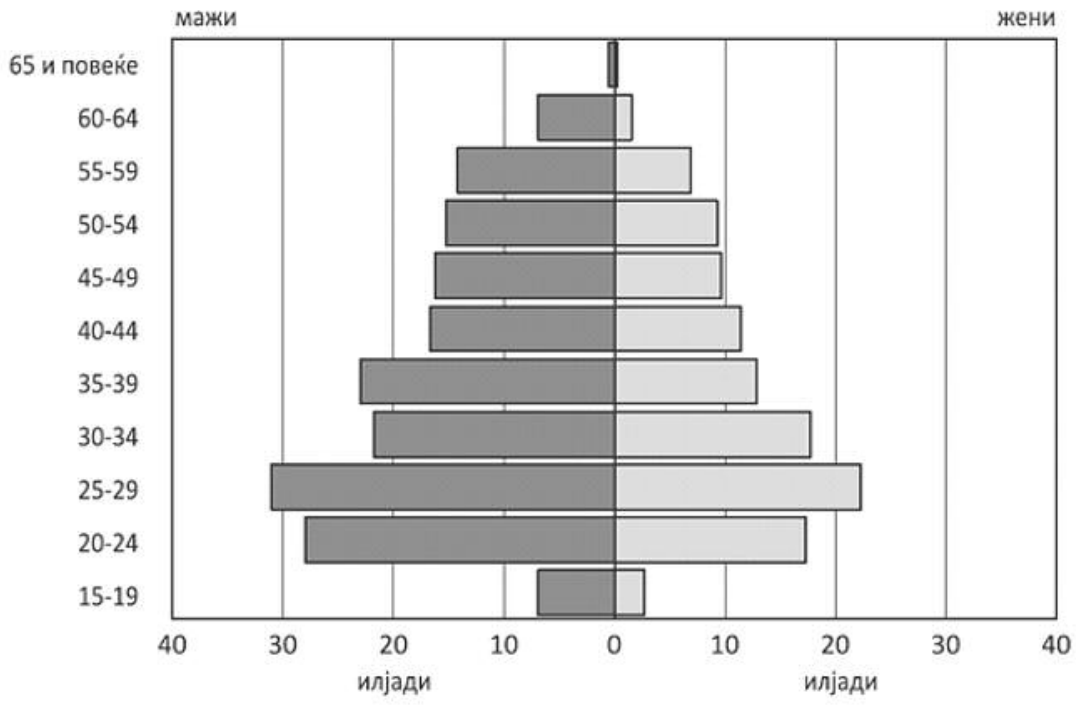

Извор: Државен завод за статистика (2013) Македонија во бројки.

Chart 2. Unemployed by age group, 2012

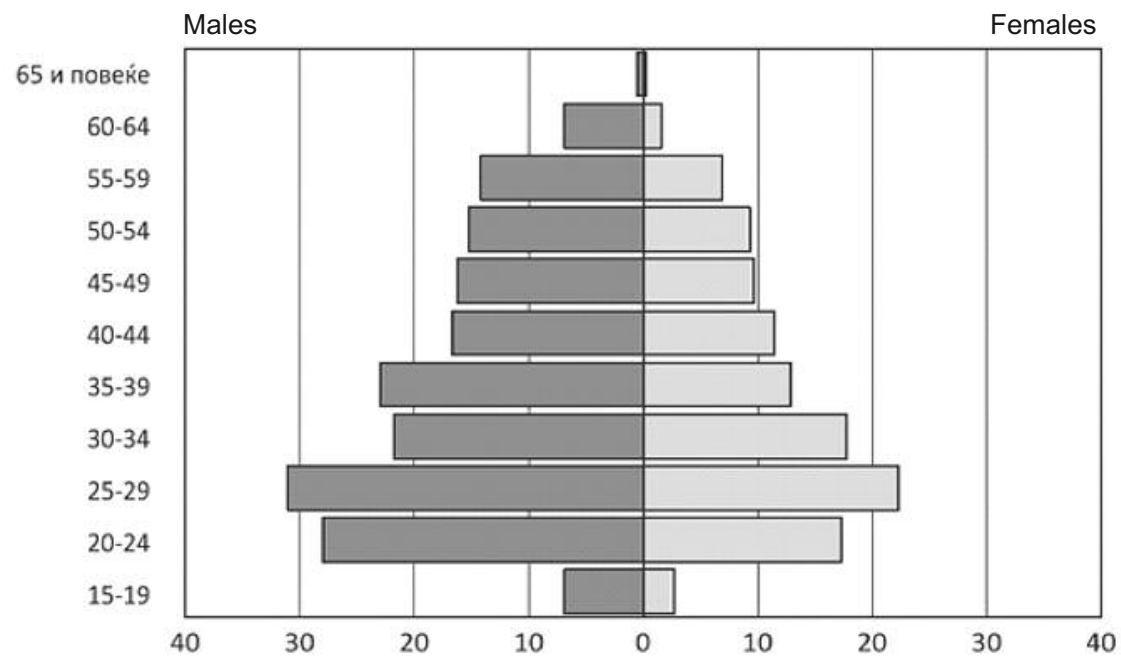

Source: State Statistical Office (2013) Macedonia in numbers.

Во вкупниот број на невработени лица, најголемо е учеството на младата популација на возраст од 20 до 29 години, а стапката на невработеност кај оваа возрасна група во 2002 година изнесува 52.5,
Young people aged 20 to 29 years have the highest share in the total number of unemployed. The unemployment rate of this age group in 2002 was 52.5 , in 2007, 48.2, and 46.1 in 2012. 
во 2007 година 48.2, а во 2012 година 46.1.

Во периодот 2002-2012 година, најголем број од невработените лица чекаат вработување повеќе од една година. Во 2012 година, нивното учество во вкупниот број на невработени изнесуваше $82.1 \%{ }^{2}$

Освен централната власт која има директни надлежности во политиките на вработување која што е и една од главните цели на секоја држава и власт, евидентна е и улогата на локалната власт во делот на вработувањето на населението кое што живее во нејзините административни граници, преку поддршка за развој на мали и средни претпријатија и претприемачи, промоција на самовработувањето локалниот економски развој и др.

\section{Демографрски показатели за Општина Чаир}

Општината Чаир опфаќа повр-

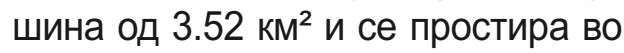
североисточниот дел на градот Скопје. Со новата територијална поделба градот го сочинуваат 10 општини, меѓу кои е и Општината Чаир. Општината Чаир е основана во 1976 година со Законот за формирање на општините, во рамките на Градот Скопје. Со новиот Закон за територијалната поделба на Република

\footnotetext{
2 http://www.stat.gov.mk/Publikacii/MK_Brojki_ 2013_m.pdf
}

In the period 2002-2012, the largest number of unemployed persons sought employment for over a year. In 2012, their share in the total number of unemployed was $82.1 \%{ }^{2}$

In addition to the central government's direct responsibilities in employment policies, local governments play also a crucial role and has instruments to improve the quality of life and employment opportunities of the citizen within their administrative borders by supporting the development of small and medium enterprises and entrepreneurs, promotion of self-employment, local economic development etc.

\section{Demographic indicators of the municipality of Cair}

The Municipality of Cair covers an area of $3.52 \mathrm{~km}^{2}$ and is located in the Northeastern part of the City of Skopje. With the new Law on territorial division of the Republic of Macedonia which defines the areas of local governments, the size of the Municipality of Cair was significantly reduced hindering therefore its development by the municipal administration.

\footnotetext{
2 http://www.stat.gov.mk/Publikacii/MK_Brojki_ 2013_m.pdf
} 


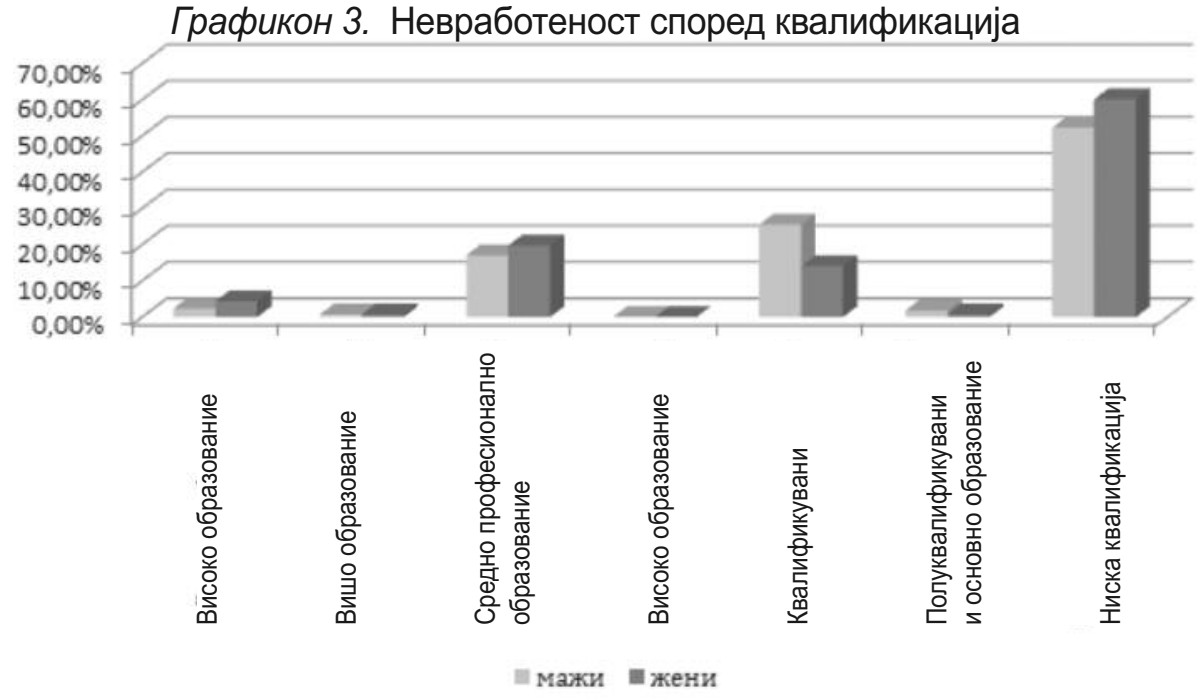

Извор: Државен завод за статистика (2013) Македонија во бројки.

Chart 3. Unemployment according qualification

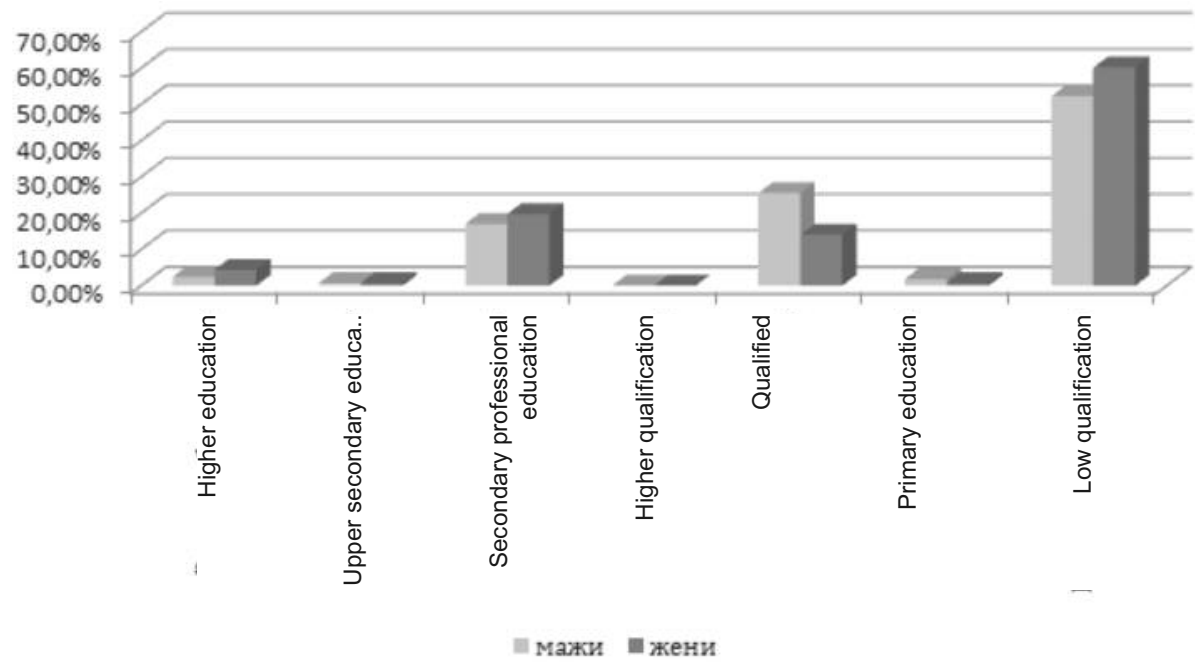

Source: State Statistical Office (2013) Macedonia in numbers.

Македонија и со определувањето на подрачјата на единиците на локалната самоуправа, границите на Општината Чаир во голема мера се стеснети, и од општинската администрација тоа е оценето како хендикеп за развојот на Општината.
The total population within the Municipality of Cair, (Census 2002) is 64,773 people or $3.2 \%$ of the overall population of Macedonia. The municipality has a high density of population with 18,400 inhabitants per square kilometer. 
Вкупниот број население, во рамките на Општината Чаир, според Пописот од 2002 година изнесува 64.773 жители или 3,2\% од целокупниот број жители на Република Македонија. Општината има голема густина на населеност со 18.400 жители на еден квадратен километар.

Структурата на населението според националната припадност е прикажана во продолжение од каде што може да се види дека доминира населението од албанско и од македонско етничко потекло со $57 \%$ и со $24,13 \%$ респективно.

Структурата на населението (популација над 15 години) според степенот на завршено образование во најголема мера е претставена од лица кои имаат завршено основно и средно училиште (41,65\% и $35,07 \%$, респективно), додека, пак, со незавршено образование се $10 \%$ и без образование $5,22 \%$ од популацијата над 15 години во Општината Чаир.

Вработеноста, т.е. невработеноста претставува проблем со кој се соочува и Општината Чаир, каде што стапката на невработеност изнесува $36,2 \%$, што е повисока вредност и од просекот на невработеност на ниво на држава, додека, пак, од 19.179 работоспособно население, вработени се 10.433, со што $45,6 \%$ се невработени. Самата структура на невработените според пол и квалификуваност е прикажана подолу. Доминираат лицата со ниска квалификација, квалификуваните и со средно професионално
The ethnic composition of the municipality includes mainly ethnic Albanians and Macedonians, with $57 \%$ and $24,13 \%$, respectively.

The educational structure of the population (over 15 years of age) is $41,65 \%$ with primary and $35,07 \%$ with secondary school, $10 \%$ with incomplete education and $5,22 \%$ with no education at all.

The municipality faces the problem of unemployment. The unemployment rate is $36 \%, 2$ which is higher than the national average unemployment rate. Out of 19,179 people in working age, 10,433 are employed. People with low qualification, qualified and with professional secondary education prevail. In terms of gender structure, unemployment among women is lower although the structure of the unem ployed is similar to men.

Within the Municipality of Cair, the most of economic activities are in the field of small and medium enterprises and entrepreneurship development and in tourism and development in the Old Bazaar. 
образование. Во однос на полова структура, невработеноста кај жените е помала иако структурата на невработени според квалификуваност е слична како кај мажите.

Во рамките на Општината Чаир доминантните економски активности се во делот на малите и средни претпријатија и во развој на претприемништвото, во развој на туризмот во Старата скопска чаршија преку: изградба на новиот плоштад Скендербег, осветлувањето во Старата скопска чаршија, осветлувањето на Општината преку ЈПП, воспоставување ефективен начин за собирање даноци и др.

Оските за локален економски развој на Општината се: развој на инфрраструктурата, промовирање на туризмот на стариот и историски дел на Градот Скопје, развој на мали и средни претпријатија и преку промовирање јавно-приватно партнерство во разни програмски инвестиции.

\section{Демографски индикатори} за Општина Јегуновце

Во Општина Јегуновце припаѓаат 17 населени места од кои 4 населени места се со голем број на жители над 1000 , останати се добро населени со над 400 жители, и 3 се со многу мал број на жители од 170 до 300. Вкупниот број на жители во општината, според последниот попис на населението од 2002 година изнесува 10790. Густината на насе-

\section{Demographic indicators of the municipality of Jegunovce}

The Municipality of Jegunovce is located in the northwest part of Dolni Polog, and is situated on the vast alluvial plain of the river Vardar. Due to its location, the Municipality of Jegunovce has a very important economic and strategic position because of the border line and the hill connecting it to the Republic of Kosovo. It is located $40 \mathrm{~km}$ away from Skopje, reaching it through the regional road P-1203 which has an international importance. It is also crossed by the railway Skopje-TetovoKichevo. The total area of the municipality is $174 \mathrm{~km}^{2}$. The Municipality of Jegunovce has 17 towns, 4 settlements with a population of over 1000 people, others are well-populated with over 400 residents, and 3 with a very small number of residents, from 170 to 300 . The total number of population in the municipality, according to the latest Census of 2002 is 10790 . The population density is 61 inhabitants per $\mathrm{km} 2$. The total number of individual households is 2645 and the average number of household members is 4.08 , which means that the size of households is quite high. The total number of dwellings is 3,029 . The 
лението е 61.01 жители на еден км². Вкупниот број на индивидуални домаќинства е 2645, а просечниот број на членови во домаќинствата е 4.08, што значи дека домаќинствата се претежно со висока големина. Вкупниот број на живеалишта е 3029.

Етничката распределба на населението е следна: 55.26\% Македонци, 43.11\% Албанци, 1.00\% Срби и $0.65 \%$ други. Образовната структура на населението во општина Јегуновце покажува слаба стручна подготовка, каде само $31,44 \%$ од граѓаните имаат средна стручна подготовка. Од друга страна, $34.50 \%$ се со завршено основно образование, но голем број на граѓани- $28.31 \%$ се со некомплетно основно образование или без образование (Попис, 2002).

Покрај тоа што општината е една од најголемите печалбарски општини во Долни Полог, како главни стопански гранки се појавува земјоделство односно агробиснис, рибарство, шумарство и рударство.

Според анкетата економски активното население во општината е $70 \%$ од вкупното население, при што $51 \%$ од него се изјасниле како вработени лица, $16 \%$ се изјасниле како домаќинки, а 33\% како невработени. Исклучувајќи го процентот на статус-вработување домаќинка, стапката на невработеност на жените (10\%) е два пати помала од просекот на ниво на државата (околу $31 \%$ ), за разлика од мажите, чија стапка е далеку поголема (23\%), спореде- ethnic distribution of the population is as follows: $55 \%$ ethnic Macedonians, $43 \%$ ethnic Albanians, $1 \%$ ethnic Serbs and $0.65 \%$ from other ethnicities.

The educational qualification of the population in the Municipality of Jegunovce is low and only $31 \%$ of the residents have completed high school. On the other hand, 35\% have completed primary education, but there are many people - $28 \%$ with incomplete primary education or with no education at all (Census, 2002). In addition, the municipality is one of the largest emigrant communities in Dolni Polog. The main industries are agriculture, or agribusiness, fisheries, forestry and mining. Excluding the percentage of those with an employment statushousewife, the unemployment rate for women $(10 \%)$ is twice lower than the national average rate (about $31 \%$ ) and lower than in men, whose rate is far higher $(23 \%)$ compared to the unemployment of women in the community, and almost $8 \%$ lower than the state average. According to the municipal authorities and development strategies of the municipality, there are opportunities for significant investment identified in the context of the development and promotion of agriculture, given the location, and there are opportunities for development of rural mo- 
но со невработеноста на жените во општината, но скоро 8\% помала во споредба со републичкиот просек.

Според општинските власти и стратегиите за развој на општината, позначајни можности за инвестирање се идентификувани во контекст на развојот и унапредувањето на земјоделството, а со оглед на местоположбата постојат можности за развој на селско-планинскиот туризам. Исто така определба на општината е да се создадат поволни услови за привлекување на инвестиции за унапредување на постоечките и нови стопански дејности. Туристичкиот потенцијал на за економски развој.

\section{Перцепцијата на младите} за невработеноста и улогата на локалната самоуправа во борбата против невработеноста во Општина Чаир и Општина Јегуновце

Примерокот е дизајниран врз основа на принципите на репрезентативен примерок, кој е избран од вкупното население на општините, врз основа на моделот на непропорционално стратификуван примерок.

Од вкупното население на општина Чаир (според пописот од 2002 година) беше избран примерок од untain tourism. Moreover, the municipal government is determined to create favorable conditions for attracting investments to enhance existing and new economic activities. The tourism potential of the municipality is defined as an opportunity for economic development. The municipal administration consists of 19 employees and work performed is distributed in the following sector units: Information, Communication and Protocol; Department for Legal and General Affairs and Public Affairs, Division of Financial Affairs, Department for Urbanism, Communal Affairs and Environmental Protection, Local Roads and Streets, and Local Economic Development.

\section{The perception of youth on unemployment and the role of local government in reducing unemployment in the municipality of Cair and Jegunovce}

The representative sample is selected from the total population of the municipalities, based on the model of disproportionate stratified sample.

Out of the total population of the municipality of Cair (according to the 2002 census) a sample of $1 \%$ was selected, i.e. 647 people were surveyed and out of the total popula- 
Графрикон 4. Општата перцепција за невработеноста кај младите

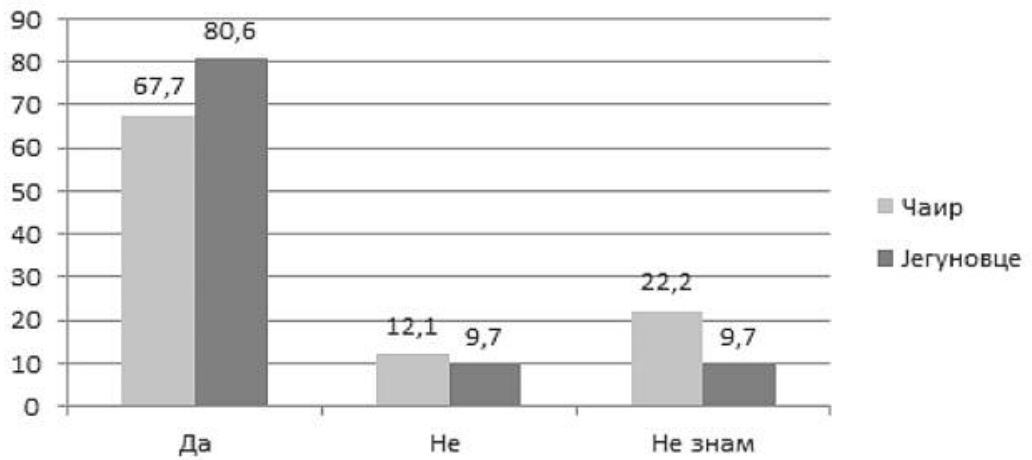

Извор: Анкета за задоволството од локален економски развој на општина Јегуновце и Чаир, декември, 2011

Chart 4. Overall perception of youth population for the unemployment

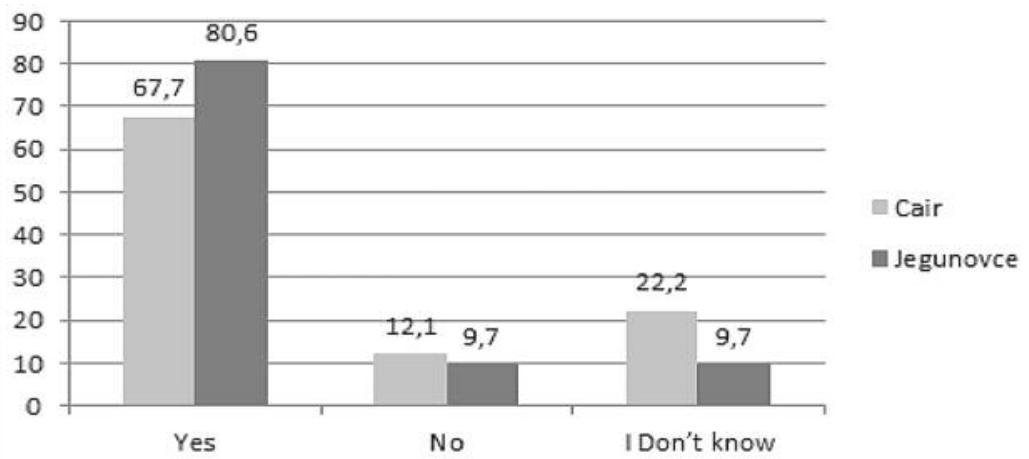

Source: Survey of satisfaction with local economic development Jegunovce and Cair, December 2011

1\% значи 647 граѓани беа анкетирани. Додека од вкупното население на Општина Јегуновце (според пописот од 2002 година), со репрезентативен примерок од $5 \%$ од вкупното население анкетирани беа 539 граѓани.

Во однос на прашањето, дали мислите дека во вашата општина има голем број на невработени резултатите се следни: во општина Чаир $77.4 \%$ одговориле со Да $9.3 \%$ со Не и $11.8 \%$ со Не знам. Во Општина Јегуновце резултатите се прилично исти и тоа со Да одговориле $87.1 \%$, со Не $6.7 \%$ и со Не знам $6.2 \%$. tion of Jegunovce (according to 2002 census) a representative sample of $5 \%$ was selected and 539 people were surveyed.

The following data are drawn from the youth respondents aged 18-25 years.

The results for the question, Do you think that your community has a large number of unemployed? are as follows: in Cair $67.7 \%$ answered Yes and, $12.1 \%$ No, 22,2 \% with I do not know. In Jegunovce youth have same perception about unemployment with 80,6 responding Yes and 
Во овој дел на истражувањето се покриени одговорите на младите од 18-25 годишна возраст.
$12,1 \%$ with No and $9,7 \%$ with I do not know.

Графикон 5. Перцепција на младите за тоа како се справува локалната власт со проблемот на невработеност

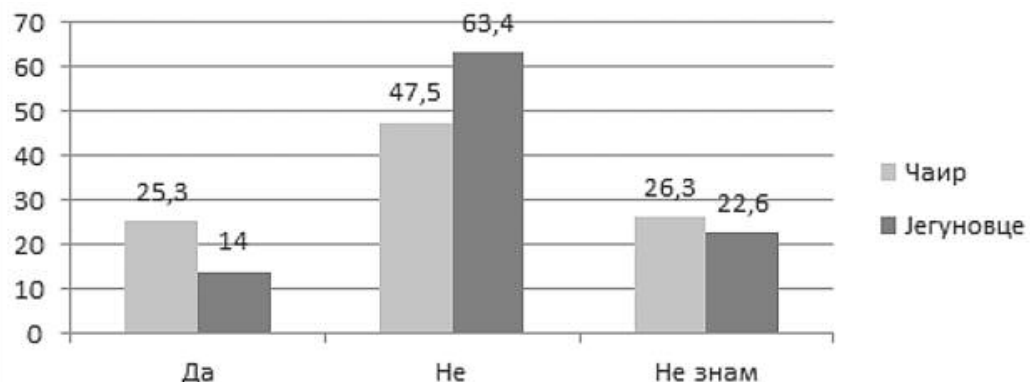

Извор: Анкета за задоволството од локален економски развој на општина Јегуновце и Чаир, декември, 2011

Chart 5. Youth perception on how the does the municipality handles the problem of unemployment

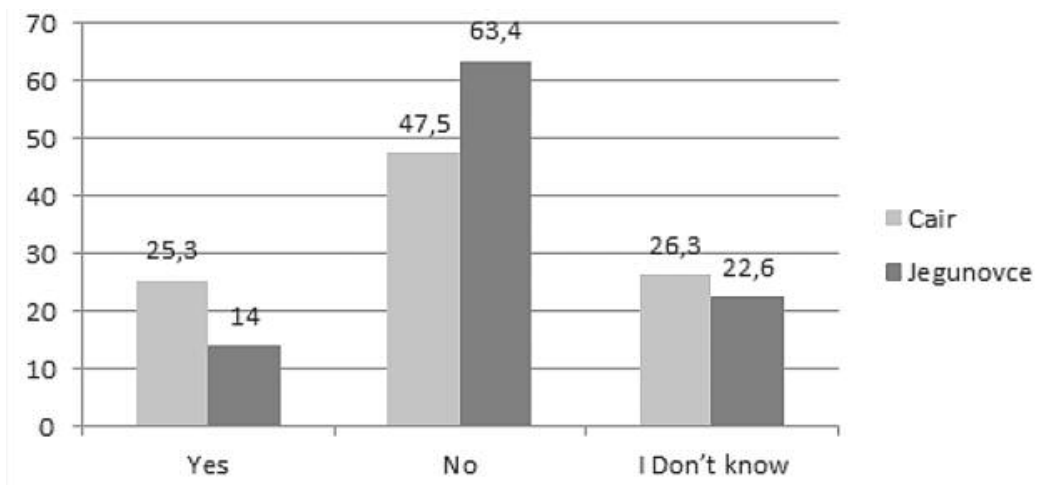

Source: Survey of satisfaction with local economic development Jegunovce and Cair, December 2011

Во однос на прашањето, Дали мислите дека локалната власт во соодветен начин се справува со проблемот на невработеност резултатите се следни: младите во Општина Чаир со Да одговориле 67,6\%, Не $12.1 \%$ и Не знам 22.4\%. Општина Јегуновце со Да одговориле Да. $80,6 \%$, Не 9,7 и Не знам 9,7\%.
Regarding the question, Do you think local government properly handles the problem of unemployment? the results are as follows: only $25 \%$ of the youth in the municipality of Cair believe that the municipality is handling properly the issue of unemployment, while $47,52 \%$ are not satisfied with the efforts of the municipality 
За овие две прашања во голема мера постои консензус меѓу различните генерации во однос на неговото третирање. Имено, различните генерации сметаат дека невработеноста во нивната општина во голема мера е присутна, додека од друга страна, истото прашање локалната власт не го третира соодветно. Младите генерации од 18 до 36 години со 70\% од своите одговори го искажуваат своето незадоволство од присутноста на невработеноста во Општината. in this sphere, $26,3, \%$ have no opinion. In the municipality of Jegunovce dissatisfaction is higher with $63,4, \%$ and $22.6, \%$ have no opinion.

It can be noted that regardless of age variable, the citizens think that unemployment in their municipality is largely present, and that this issue is not adequately addressed by the local government. In addition, $70 \%$ younger generation (18 to 36 years) expressed dissatisfaction with the high unemployment rate in their municipality.

Графрикон 6. Невработеноста - генерациска перспектива

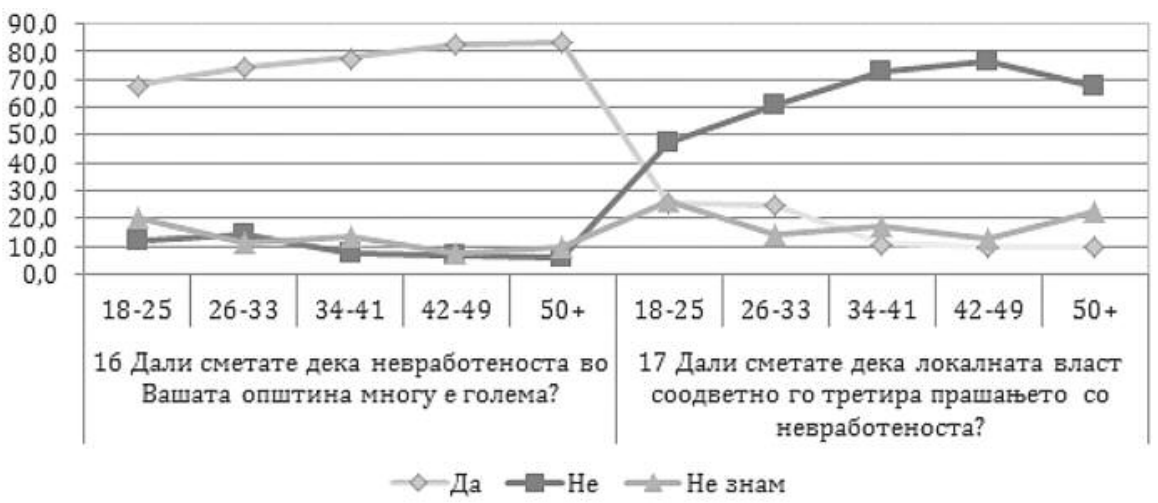

Извор: Анкета за задоволството од локален економски развој на општина Јегуновце и Чаир, декември, 2011

Chart 6. Unemployment - generational perspective

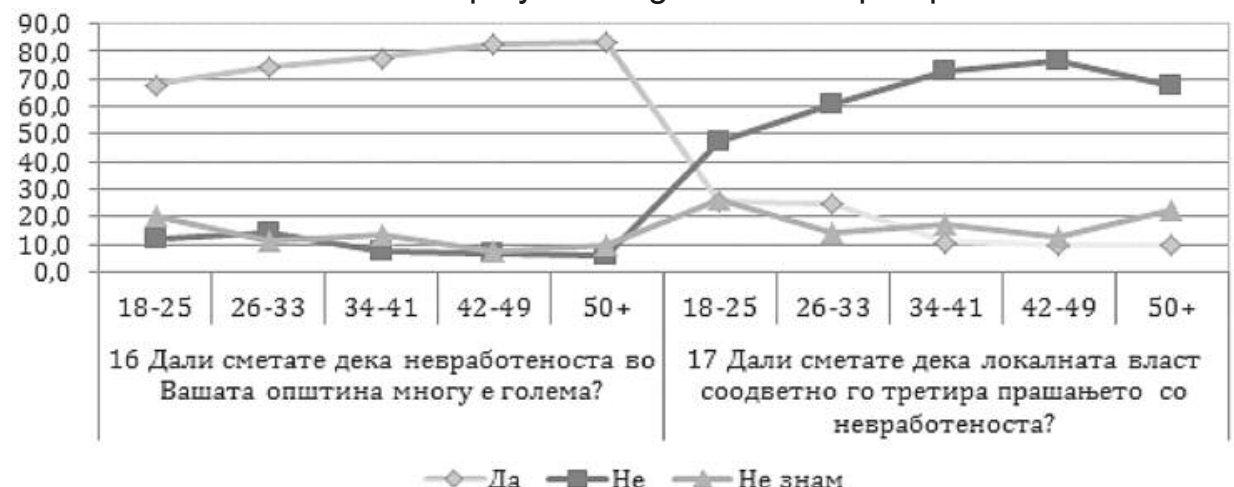

Source: Survey of satisfaction with local economic development Jegunovce and Cair, December 2011 
Во врска со ова прашање. Како принципот на еднаквост во вработувањето во општинската администрација, резултатите се како што следува: Чаир, принципот на правичност со $25,3 \%$, доминирана од страна семејни врски (непотизам) со $17,2 \%$, доминирана од страна на партиските врски со $31,3 \%$, со не знам $32,3 \%$. Јегуновце, принципот на еднаквост на $5,4 \%$, доминирана од страна семејни врски (непотизам) со 20,4 \%, доминирана од стра-
Regarding the question of equality, in terms of equity in employment in the municipal administration, the results are as follows:

In the municipality of Chair, only $25,3 \%$ of the youth believe that employment in the administration are carried out through fair procedures, $17,2 \%$, argue that the main criteria are family connections (nepotism), political affiliation is argued by $31,3 \%$, and $32,3 \%$ have no opinion regarding that question. In the

Графрикон 7. Перцепција на младите за применувањето на принципите на правичност при вработување

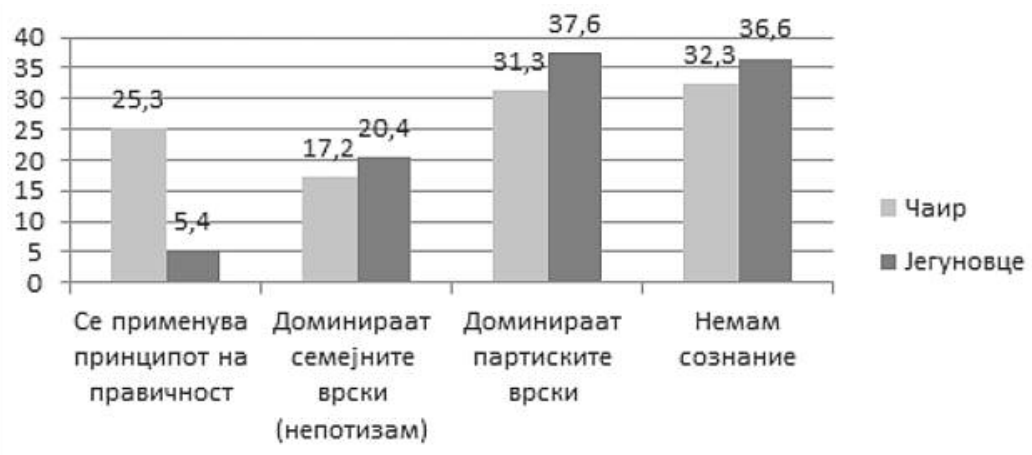

Извор: Анкета за задоволството од локален економски развој на општина Јегуновце и Чаир, декември, 2011

Chart 7. Youth perception of LED on principle et equality in employment

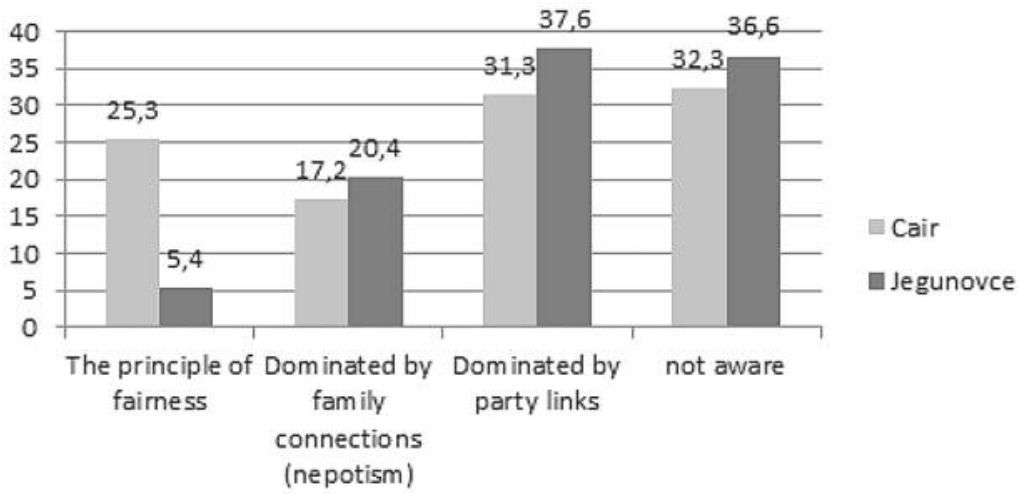


на на партиските врски со $37,6, \%$, со не знам за $36,68 \%$. Од одговорите произлегува дека поголемиот број од младите анкетирани во оваа истражување сметат дека вработувањето во општинската администрација не се реализира врз основа на принципот на правичност.

Во областа на локалниот економски развој, како клучен елемент на локалната самоуправа во кои општините имаат ингеренции и можат да придонесат за намалување municipality of Jegunovce results are disappointing as well. Only 5,4 $\%$ of the respondents are confident that municipality applies fair procedures when employing, $17,2 \%$ believe that nepotism is the main reason and $37,6 \%$ think that party affiliation is crucial and $36,6 \%$ have no opinion on the issue.

The area of local economic development is the key area where municipalities can contribute directly and indirectly in improving the em-

Графрикон 8. Перцепцијата на младите за ЛЕР Чаир

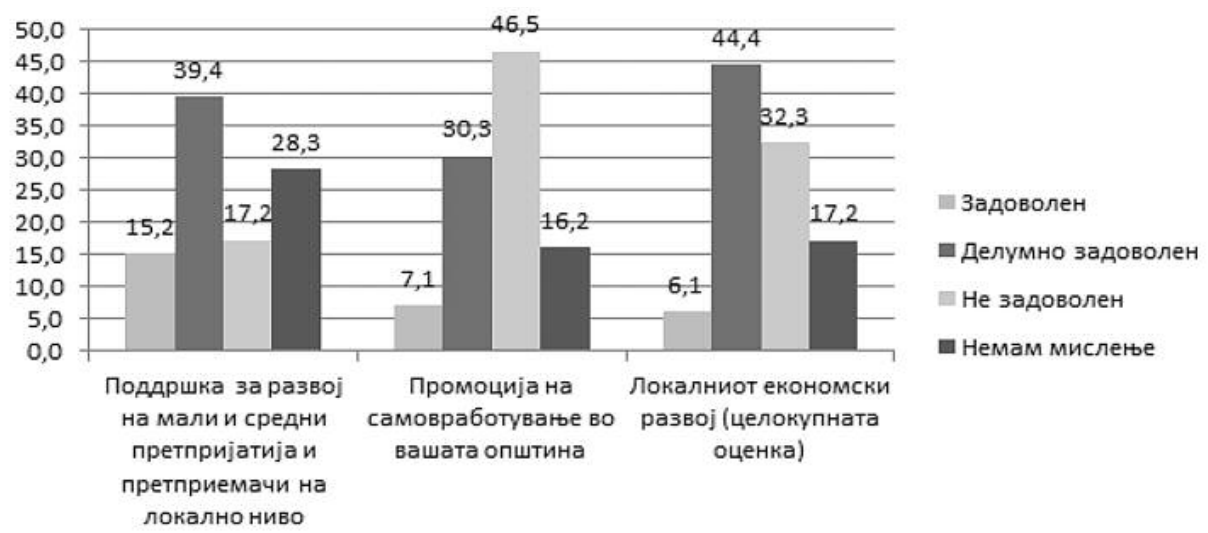

Извор: Анкета за задоволството од локален економски развој на општина Јегуновце и Чаир, декември, 2011

Chart 8. Youth perception of LED in CAIR

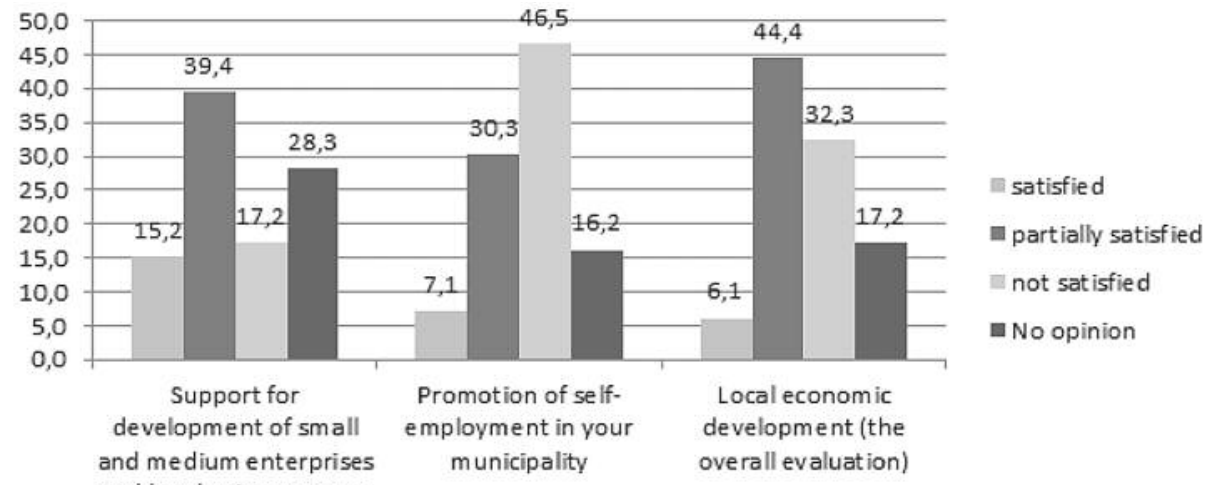
and local entrepreneurs

Source: Survey of satisfaction with local economic development Jegunovce and Cair, December 2011 
на невработеноста, на испитаниците им беа поставени следните три прашања: Колку се задоволни од поддршката од страна на локалните власти за развојот на малите и средни претпријатија и претприемништвото, Промоција на самовработување во вашата општина и Локалниот економски развој (целокупна оценка). Разултатите се прилично негативни и тоа: Во врска со прашањето за поддршката од страна на локалните власти за развојот на малите и средни претпријатија и претприемништвото, мнозинството ployment prospects of the municipality. Local government can assist and promote small and medium enterprises, promote self-employment and economic development in general. Youth respondents were asked three questions as: How pleased you are with the support for the development of small and medium enterprises and entrepreneurs at local level, promotion of self-employment in your community and local economic development (overall evaluation). The results show that there are

Графикон 9. Перцепцијата на младите за ЛЕР Јегуновце

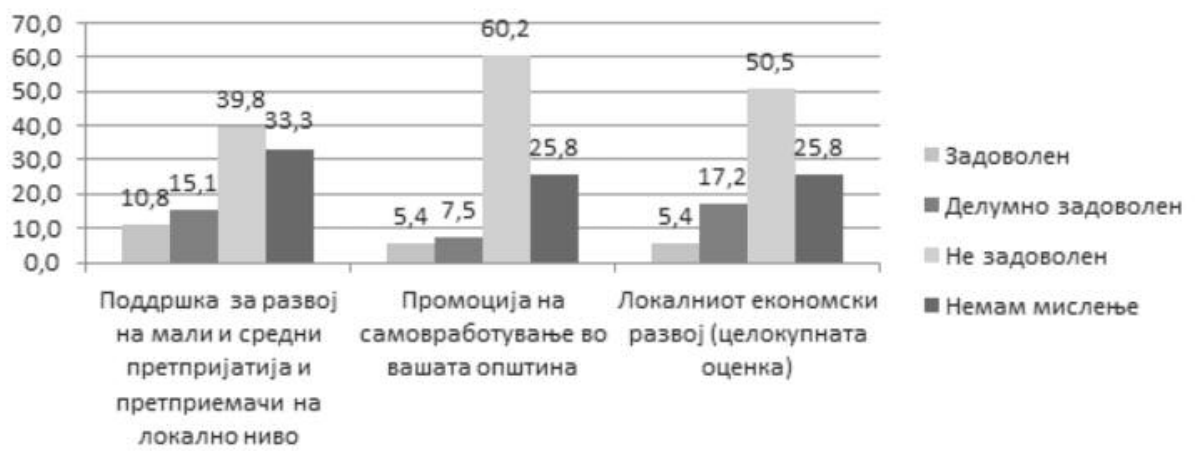

Извор: Анкета за задоволството од локален економски развој на општина Јегуновце и Чаир, декември, 2011

Chart 9. Youth perception of LED in Jegunovce

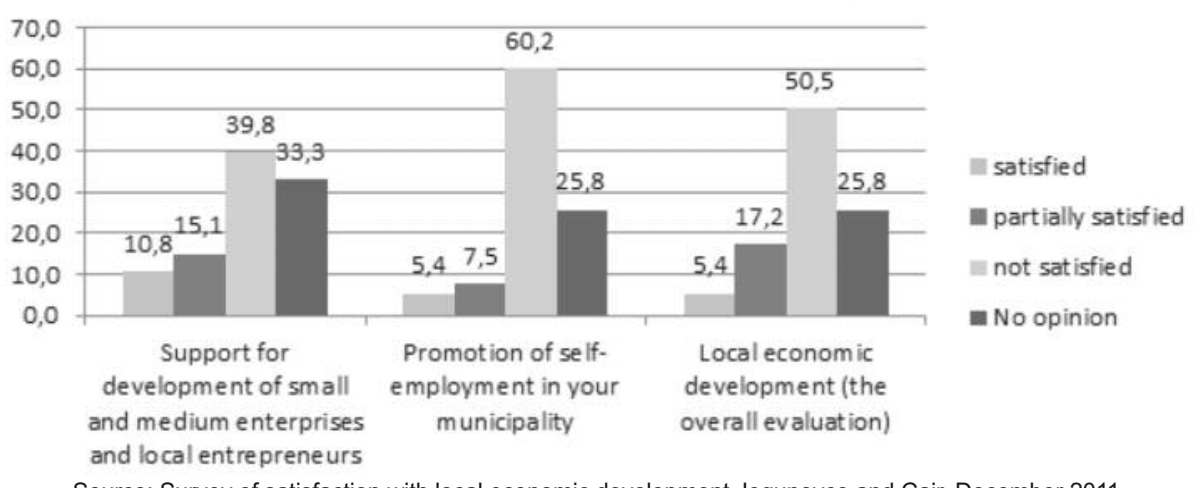

Source: Survey of satisfaction with local economic development Jegunovce and Cair, December 2011 
од младите испитаниците 44,8\% беа делумно задоволни наспроти $19,1 \%$ незадоволни. На прашањето колку се задоволни од промоцијата на самовработување во вашата општина, мнозинството од младите испитаници односно, 46,5\% не се задоволни наспроти 7,2 кои се задоволни. На прашањето колку се задоволни од локалниот економски развој (целокупната оценка), 32,3\% од младите не се задоволни наспроти $6.1 \%$ кои се задоволни. Како констатација произлегува дека младите очекуваат многу повеќе во локалниот економски развој како влезна точка за подобрување на можностите за вработување во општина Чаир.

Во врска со овие прашања резултатите од истражувањето во Јегуновце се уште по негативни и тоа на прашањето за поддршката од страна на локалните власти за развојот на малите и средни претпријатија и претприемништвото, мнозинството од испитаниците $40 \%$ одговориле дека не се задоволни наспроти $10,0 \%$ кои што одговориле дека се задоволни. На прашањето колку младите се задоволни од промоцијата на самовработување во вашата општина, мнозинството од испитаници, $60 \%$ одговориле дека не се задоволни наспроти 5,4\% кои одговориле дека се задоволни и во однос на прашањето за локалниот економски развој (целокупната оценка): 50,5 \% се незадоволни наспроти 4,2\% задоволни. avenues for improving the level of satisfaction in this area as well. Accordingly, in the municipality of Chair, $15,2 \%$ of the respondents are satisfied with the support for development of small and medium enterprises and $17,2 \%$ are dissatisfied with the situation. Regarding the question of promotion of self-employment in the community results exemplify that $46,5 \%$ are satisfied with the promotion of self-employment. Regarding the Local Economic Development (overall rating) $32.3 \%$ of respondents are not satisfied with efforts of the municipality of Cair.

In the municipality of Jegunovce the results are as follows: support for development of small and medium enterprises and local entrepreneurs, $39,8 \%$ of youth are not satisfied versus $10.8 \%$ who are satisfied. Regarding the question: Promotion of self-employment in your community, $60,2 \%$ dissatisfied versus $5,4 \%$ who are satisfied and question local economic development (overall rating): $50.5 \%$ dissatisfied versus 5.4 who are $\%$ satisfied. 


\section{Заклучоци \\ и препораки}

Врз основа на горенаведените наоди од компаративната анализа за перцепцијата на младите во врска со невработеноста може да се издвојуваат следниве заклучоци: Локалниот економски развој претставува влезна точка преку која општината може да влијае во намалување на проблемот на невработеноста на младите. Голем е процентот на невработеност, посебно кај младата популација, при што не постојат развиени институционални механизми за ангажман на овој сегмент на популацијата.

Постои потреба од скрининг на релевантниот локален/регионален/ национален приватен сектор и на граѓанското општество, кои имаат широка мрежа, добра репутација и се способни да мобилизираат млади и други специфични ранливи групи и да генерираат основање социјални партнерства за инклузивна испорака на услуги и за воспоставување соработка за инклузивен локален развој.

Неопходно е мапирање на (постојните и потенцијалните) модели на социјално претприемништво општествено одговорни економски иницијативи кои можат да привлечат инвестициски фрондови во локален контекст.

\section{Conclusions and recommendations}

Based on the above findings of the comparative analysis of the perception of youth about unemployment we can draw the following conclusions: Local economic development is the entry point through which the municipality can contribute in reducing the problem of youth unemployment. There is a large percentage of unemployment, especially among young people, and thus there is a need for developing institutional mechanisms for engagement of this segment of the population.

There is a need for screening of relevant local / regional / national private sector and civil society, via networking, good reputation and areable to mobilize young people and other vulnerable groups to generate establishment of social partnerships for inclusive service delivery and establishing cooperation for inclusive local development.

There is a need for mapping the (existing and potential) models of social entrepreneurship - socially responsible economic initiatives that can attract investment funds in the local context.

There is a need for mapping of the potential of Inter municipal cooperation (IMC) arrangements related to local economic develop- 
Потребно е мапирање на потенцијалните аранжмани за меѓуопштинска соработка поврзана со локален економски развој, ${ }^{3}$ како и на целокупните можности за јавно-приватни партнерства и за издавање концесии во насока на намалување на трошоците за администрацијата или намалување на трошоците за обезбедување услуги кои имаат влијание врз локалниот економски развој и врз стапката на (не)вработеност во заедницата.

Неопходно е да се воспоставуваат институционални механизми за младински ангажман, вклучувајќи Социјална програма за претприемништво на младите (ССПМ).

Воспоставување иницијативи за ССПМ преку трилатерални партнерства: младите и младинските организации/локалните функционери/приватниот сектор.

Да се креира локален младински форум / совет, со цел да ги рефрлектира гледиштата на младите во

\footnotetext{
3 Како што се: регионален рурален развој; заедничко спроведување агроеколошки мерки, вклучувајќи го создавањето на локални акциони групи; бизнис, трговија и економски развој (вклучувајќи ги и вештините за развој на човечкиот капитал); заеднички развој на туризмот и други мерки за привлекување инвестиции; заедничка администрација / јавни комунални претпријатија и соработка за развој на регионална еколошка инфраструктура; заедничко планирање за катастрофа - намалување на ризикот; подобро управување со заштитените подрачја; заеднички установи за интегриран /инклузивен развој во заедницата и други.
}

ment $^{3}$ and the overall opportunities for public- private partnerships and issuing concessions aimed at reducing the cost of administration and reducing costs for providing services that affect local economic development and the rate of (un) employment in the community.

It is necessary to establish institutional mechanisms for youth engagement, including Social Entrepreneurship Program on Youth (SSPM).

It is important to work on establishing initiatives SSPM through trilateral partnerships: youth and youth organizations/local officials /private sector.

It is indispensible to create a lo cal youth forum / advice in order to reflect the views of young people in the community for the most critical needs. Thus contributing to the creation within the local and national policy and programming to demonstrate and implement innovative services at the local level.

\footnotetext{
3 Such as regional rural development, joint implementation agri-environment measures, including the creation of local action groups, business, trade and economic development (including skills development of human capital), joint development of tourism and other measures to attract investment; joint administration / public utilities and cooperation on regional environmental infrastructure joint planning for disaster - risk reduction, better management of protected areas, common facilities for integrated / inclusive development community and others.
} 
заедницата за најкритичните потреби. На тој начин да придонесе кон креирање рамки на локалните и националните политики и да демонстрира програмирање и спроведување иновативни услуги на локално ниво.

Превод на ССПМ во соодветно буџетирана општинска програма, со цел да се обезбеди одржливост на ССПМ, преку финансирање на проекти поврзани со младите и функционирањето на локални младински партиципативни тела.
Municipalities should earmark parts of the budget to SSPM in order to ensure sustainability of SSPM by funding projects that are related to youth projects related to youth and functioning of local participatory bodies. 


\section{Литература/ Refferences:}

- Bastiat, F. (1995) Selected Essays on Political Economy, Irvington-on-Hudson, NY: The Foundation for Economic Education.

- Gersemann, O., (2004) Cowboy Capitalism: European Myths, American Reality, New York: John Wiley \& Sons and Cato Institute.

- International Labor Organization (2013) "Global employment trends 2013", Geneva: ILO,

- International Labor Organization: (1982) Resolution concerning statistics of the economically active population, employment, unemployment, and underemployment, adopted by the Thirteenth International Conference of Labor Statisticians, Geneva, ILO.

- Odekon, M. (Ed.). (2006). Encyclopedia of world poverty. Thousand Oaks, CA: Sage Publications.

- State Statistical Office (2013) Macedonia in numbers, Skopje:

State Statistical Office http://www.stat.gov.mk/Publikacii/MK_Brojki_2013_m.pdf

- Vedder, R. K. and Gallaway, L.E. (1997) Out of Work, New York:

New York University Press 